\title{
ROLE OF APPLIED ETHICS(CIST) IN MANAGING THE QUALITY OF LIFE IN THE POST-RISK SOCIETY
}

\author{
Daniela FOBELOVÁ \\ Sliesian University of Technology \\ University of Matej Bel \\ Lukáš MORAVEC \\ Elena BENDÍKOVÁ \\ University of Matej Bel
}

\begin{abstract}
:
The presented study focuses on the role of applied ethics(cist) in managing the quality of life in the post-risk society. Given that, from an ethical point of view, it is appropriate to reflect the quality of life also through other than quantitative, i.e. objective and therefore also measurable indicator, it is important to be also focused on the action of a person that leads to increasing his/her satisfaction, the feeling of happiness as a subjective indicator. The aim of this study is to point out the importance of ethical parameterization of the quality of life as well as the search for suitable concepts in its fulfilment.
\end{abstract}

Key words: applied ethics, good life, risk society, well-being, quality of life

\section{INTRODUCTION}

One of the most discussed concepts of the twentieth century society since 1986 has been the "risk society", "reflexive modernity", "forced individualisation" by the author Ulrich Beck. As the author himself states, the ideological thread of his thinking is to reflect on the grave moral problem of the mankind, that the human society is able to endanger itself by its own progress. „In this sense, the risk society is potentially at the same time the self-critical society. The criticism of the risk is a normative criticism of values. Risks arise from where the traditions, and thus the values, are distributed. The basis of the criticism is, rather than the traditions of the past, the threat of the future. To identify the toxic substances in the air, water and food, the costly measuring instruments and methodological and theoretical knowledge are required rather than valid values. Risk assessment ... does not apply the moral measure openly but in the form of quantitative-theoretical-causal implicit morality" [2]. Although the author does not use the notion of quality of life as a key concept in his works, we find the basis for its exploration in his texts. In the twentieth century, the community of misery was replaced by a community of fear (both historical and natural disasters were witnesses). All recorded events had a fundamental impact on the quality of life (or the good life) of each individual as well as the whole society at that time.
Today we live in the twenty first century and the time has come to evaluate whether the humanity has learned from these disasters and how this has affected the quality of life of this century man.

QUALITY OF LIFE - A GOOD LIFE IN THEORY AND PRACTICE On the theoretical level, we have to state that, although there are plenty of quality of life definitions, there is not one that would be universally accepted by the scientific community since this concept began to be used as a scientific one. The problem is also due to the fact that, besides the concept of quality of life, the concepts - social satisfaction, social well-being, good life and others - are also used, which are not perceived as synonyms by the content, are used as well. As it still reflects the twentieth century in the search for the elimination of deficiency, misery, deprivation (perhaps because there is still a lot of it in the world).

What we can agree with is that quality of life can be thought of as a consequence of the interaction of many factors - economic, health, environmental, social, and others, that affect the lives of individuals and societies. It follows that quality of life has an objective as well as subjective aspect. If we generalize, the objective side of quality of life is more measurable, it touches on the social and material conditions of life. The subjective side of 
quality of life, which is harder to measure (if at all possible), relates to man's satisfaction with life, emotional experience or even a good life.

Quality of life is a multidimensional concept that is used in various disciplines, which is why it is problematic to find a universal definition, whereby the concept acquires different meaning in content which is dependent on the sphere of application. In the Oxford online dictionary, the term is defined as "quality of life - the standard of health, comfort, and happiness experienced by an individual or group" [4]. The issue of quality of life is also addressed by many organizations (e.g. OECD Better Life Index [11], EUROSTAT - Quality of life [6], the quality of life from the aspect of health is addressed by the WHO Quality of life [14] and NUMBEO [10] addresses the conditions for life, especially in the financial aspect). In addition, the above-mentioned organizations carry out the research on the quality of life in the given area, according to their specific methodologies, but accept a combination of objective and subjective indicators. The first idea, the idea from which we are based, is the quote on the page of OECD Better Life Index. "There is more to life than the cold numbers of GDP and economic statistics" [5]. The quote opens up the reflection of the concept of quality of life in the sense that there is more to life than just the money and numbers. The quality of life is reflected in the above-mentioned aspects through several indicators, which are a combination of objective and subjective indicators.

Our previous opinion is confirmed by the author Michalos [9], who discusses the importance of interconnection of the policy, objective and subjective factors in the encyclopaedia of applied ethics with his opinion in the part business ethics and quality of life "Because, morally speaking, our commitment ought to be not merely to improving people's (subjective) feelings and attitudes about their lives but also to improving the very (objective) conditions in which they live their lives, defining our basic principle of beneficence in terms of the quality of life seems to be most appropriate“ [9].

In Slovakia, the quality of life is addressed by the several authors, most often we can come across the theological, psychological, economic, environmental and health aspects. These are mostly scientific papers, conference papers, studies. For the needs of applied ethics, we consider the most beneficial the studies from the field of psychology because they accept the subjective evaluation of life, they address the dimensions of well-being, good life, happiness, life satisfaction. These are the authors Jozef Džuka, Mária Antalová, Lucia Pašková, Vladimír Salbot, Jiří Mareš, Daniela Fobelová, Pavel Fobel who are based mainly on European ideological sources. From the point of view of ethics, it is important to emphasize the need to monitor the quality of life in the long run and to avoid the affective states (short-term impact) in the assessment.

The subjective aspect of quality of life needs to be defended from the aspect of relevance. The European Commission has conducted an extensive study on the subject of the measurement of economic performance and social progress in which the definition of quality of life is stated as follows "Quality of life is a broader concept than economic production and living standards. It includes the full range of factors that influences what we value in living, reaching beyond its material side" [9]. In Encyclopaedia of Applied Ethics, the definition is different "quality of life - a fairly modern term used to designate what ancient philosophers would have referred to as a good life" [6]. At the same time, the quote also points to the interconnectedness of the quality of life and good life. The good life is parametrized as follows: "Good life - overall well-being as defined by the individual, when the individual is free to form her or his definition without coercion and with adequate relevant information" [1]. Good life can firstly be determined, characterized by the concepts such as good, justice, happiness, living in a good society, identifying a good life, visions of fulfilled life, whereby all the concepts are ethical categories. Applied ethics works with post-foundationalism tools that develop moral sensitivity, a vision of good life, therefore, it is possible, and needed, to ethically parameterize the given issue.

The issue of quality of life is mainly associated with statistical results that express the level of quality of life. The problematic part is the analysis of the used methodologies and the monitored indicators, since they differ from the scientific discipline that examines the quality of life. The fundamental problem is the issue of objective factors and subjective evaluation.

Objective factors can be captured and parameterized without any major problems. In subjective assessment, it is more complex, the subjective, emotional aspect enters the evaluation process. A subjective opinion can assess subjective quality of life or subjective perception of well-being.

An important principle in determining the subjective aspect of quality of life is to look at the assessment of life from the long-term aspect. The solution is to focus on long-term life, long-term assessment of the factors affecting life as a whole and its individual factors. This prevents an influence of the emotional affective side, but the phenomenon cannot be avoided altogether. The impact of evaluative affects can distort the results, but accepting the subjective aspect of assessment is necessary, especially in terms of applied ethics.

The whole concept of quality of life is based on the assessment of life as a quality life by the people, whereby it is possible to find the efforts to find a good life in the entire philosophical tradition. However, the opinions on quality life have changed, it is not a universal theory, it has to be examined contextually. "A long philosophical tradition views individual as the best judges of their own conditions. This approach is closely linked to the utilitarian tradition but has a broader appeal due to the strong presumption in many streams of ancient and modern culture enabling people to be happy and satisfied with their life as a universal goal of human existence" [13]. Our viewpoint - accepting the subjective aspect of the quality of life assessment can be declared by several other opinions. It is a common phenomenon to consider 
GDP growth as the improvement of the quality of life, as the quality of life is rising alongside GDP growth. Author Selin Kesebir, also devoted to the issue of GDP growth and well-being growth, she has found out in her research that GDP growth has not always equalled to the growth of the well-being. The growth of the economy does not make people happier. "What we can say for sure, is that it's a fallacy to equate GDP with well-being" [8]. Our findings point to the independence of the subjective assessment of the quality of life - well-being and its subsequent relevance for the research.

Well-being is closely linked to the quality of life. In encyclopaedia of Applied Ethics it is defined as "well-being is a view here as a measure of what an individual can achieve (functioning) given that individual's advantages or real opportunities (capabilities) to realize a particular level of the good life or socioeconomic well-being" [1]. Oxford online dictionary provides quite brief definition of well-being "the state of being comfortable, healthy, or happy"[4]. The interconnection of quality of life and well-being is demonstrated by the author Dower as follows „quality of life - the overall character of a person's life assessed in terms of how well (or badly) that person achieves well-being. The criteria by which this is assessed are complex and a matter of disagreement, with some stressing economic or material standing and others stressing factors such as social relationships, community, liberty, and relationships to the natural world" [3]. Well-being is also a multidimensional concept.

Well-being is about the possibilities the individual can achieve, about his perspectives, his ideas, it is the vision of the good life to work with, which he is about to approach. This is not a minimum of security/standards in the form of welfare, which are guaranteed. Access to education is an important thing but it is different to have access to basic education and to be able to achieve university education, especially at a first-rate university. Working for a minimum wage is different than working for a wage which represents a higher standard and also has other benefits. The issue is expanding, because it will be more complicated to look for the mechanisms that fulfil the quality of life from a social point of view. Every person is a unique being, and we deduce that different people will also have different needs and expectations. For this reason, research is also important on the aspects of good life that create it, or what people consider a good life. Quality of life, or in other words the dimensions of quality of life (both objectively and subjectively) should be included in creating the political programs. Because it is not enough to provide a basic standard of living for people (to ensure basic well-being) in the form of welfare support for socially disadvantaged groups of people in a way of equal opportunities. It is necessary to develop and promote the improvement of the quality of life of all citizens and, without political support and systematic approach, this will not be possible. Support strategies of quality of life improvement (both objective and subjective indicators) need to be included in the program statements of the governments. Politics should no longer focus on restrictive measures only, but they should pursue a proactive politics of improving the quality of life, not only in the form of welfare, as helping the most disadvantaged and equalizing their chances. It is necessary to accept the importance of social fields and especially applied ethics, which will help achieve the given objectives, as it deals with the issues of values, visions, good life. There is a need for government, scientists and practitioners to cooperate in the field of social sciences as well, since it is necessary to improve the quality of life also from the subjective aspect of assessment, while considering cultural, religious and other aspects. Suggestions for the solutions will be contextually parameterized. It is important to create the projects and strategies, to promote activities that contribute to better relationships in the society, openness, satisfaction, when people have the opportunity to seek self-realization.

In the above-mentioned report, the authors Stiglitz, Sen, Fitoussi express the importance of implementing new ways of formulating the politic strategies „The Report is addressed, first of all, top political leaders. In this time of crises, when new political narratives are necessary to identify where our societies should go, the report advocates a shift of emphasis from a production-oriented measurement system to one focused on the well-being of current and future generations, i.e. toward broader measures of social progress.... the report is aimed at reaching policy-makers who wish to get a better sense of which indicators are available and useful to design, implement and assess policies aimed at improving well-being and foster social progress" [13].

\section{THE ROLE OF APPLIED ETHICS IN MANAGING QUALITY OF LIFE}

Factor that significantly affect the quality of life is work (its plenitude or shortage and therefore unemployment that results in poverty and endangering good quality of life). Employment, work plays an extremely important role in the life of every responsible person. Above all, the work provides a person, besides money - a financial source, also with the belonging to the society, i.e. it shapes its social status and promotes a good or quality life. If a person loses it in the course of time, he loses self-esteem and feels unneeded and inferior, or even it is confirmed by the experience, that he loses the verified abilities and skills acquired by the learning and practice. It is important, if it is at the least possible, for every "potentially" unemployed person to create a financial reserve - savings for a particular situation. No less important is the moral support of the family members as well as friends. In Europe, and especially in the Middle and Eastern, despite the fact that unemployment is declining, the percentage of long-term unemployed people, especially young people, is too high.

The statement by J. Rifkin sound optimistic: "Europeans work to live, rather than live to work". However crucial the work is for their lives, it is not enough to define their existence. They place amusement, social capital and solidarity above the career. When asked what values are extremely or very important to them, $95 \%$ of them put 
the help to others at the top of the list of priorities; $92 \%$ said it was extremely or very important to appreciate people for what they are, $84 \%$ declared that they highly value the engaging in creating a better society, $70 \%$ appreciate the dedication of more time and effort to the personal development, and only less than a half of them $49 \%$ said that it is extremely or very important to produce more money. Financial success is in the list of eight values listed in the survey, stated in the last place" [12]. The role of applied ethics(cists) is the prevention and to prevent immoral actions and activities in different areas of life in order to achieve and manage a good or better quality of life. In the case of employment (unemployment), a number of moral norms fulfil their role, which should from the ethics and employment ethics point of view direct a person's way of life so as to point to his quality of life, which we could describe as a good quality of life or a good life. Money, wage is only one factor that can improve the quality of life for many members of society. We are all well aware that money does not guarantee health or happiness; at the most, they can only ensure that one is not hungry and has a roof overhead, or he can afford some accessible bliss.

According to the authors of the study, Pavel Fobel and Monika Fobelová: „Happiness is one of the main goals of every person's life, but also a way of finding a balance between economic growth and its impact on society and the environment. Putting this indicator into human practice can mobilize us to create a better future, to a higher quality of life and to its sustainability" [7].

Quality of life is closely linked to the average life expectancy and hence to care for health that is linked to a good environment. In this connection, the sub-disciplines of applied ethics, such as medical ethics, environmental ethics, as well as ethics of science and technology, fulfil their role in the areas influencing the quality of life. In this respect, an adequate and at the same time very rapid reflection of applied ethics is necessary in the most varied innovations that $21^{\text {st }}$ century mankind encounters every day.

This adequate challenge of the $21^{\text {st }}$ century, touching on innovation of the most varied type, desires the representation in the form of competent applied ethicists - consultants and ethics advisers in creating an ethical environment. Even though the current time does not allow the humanitarians to present themselves in practice, in a new community dominated by the new technologies and techniques. The need for applied ethicists will grow with the growing need to process the amount of innovations.

\section{CONCLUSION}

We live in a specific time and environment where the different models involved in creating conditions for a quality, good, happy life meet in competition. At the moment, the technical one is superior to the humanitarian one (applicational - ethical), but we hope it is only a temporary solution, as witnessed by our ancestors in the 1940s. For ultimately, it is the quality of life, the good life, the well-being or the happiness of a person who strives for it.

„Europeans want to be globally interconnected without losing the sense of cultural identity and locality. They find their freedom in relationships, not in the autonomy. They are trying to live a good life here and now, what means for them to live in a sustainable relationship with the planet Earth in favour of the interests of those who come after them. Eight out of ten Europeans say they are happy in life. And when Europeans are questioned, what is the most important message of the 20th century, 58\% of them choose the quality of life, and in the list of eleven items they put it on the second place right after the freedom. $69 \%$ of Europeans also feel that the current and urgent issue is the protection of the environment" [12]. Rifkin called this state a European dream, which has a great chance of success and following of the people living here. This would be a shining light of the good times and a good happy or quality life for the people of good will on the planet Earth.

\section{ACKNOWLEDGMENT}

The authors would like to thank Agency APVV for their support of the APVV-17-0400 project "Enhancing the Ethical Environment in Slovakia (Institutional Procedures, Actors, Risks, Strategies)". This article was created as part of the project.

\section{REFERENCES}

[1] N. Altman. "Sen's Capabilities and Economic Welfare“, in Encyclopedia of Applied Ethics, $2^{\text {nd }}$ ed., vol. 4. R. Chadwick, Ed. Amsterdam: Elsevier Academic Press, 2012, p. 61.

[2] U. Beck. Riziková společnost'. Na ceste $k$ jiné moderně. Praha: SLON, 2004, p. 293.

[3] N. Dower. „Development Issues, Enviromental“. Encyclopedia of Applied Ethics, $2^{\text {nd }}$ ed., vol. 1. R. Chadwick, Ed. Amsterdam: Elsevier Academic Press, 2006, p. 789.

[4] English Oxford Living Dictionaries. „Quality of live“. Internet: https://en.oxforddictionaries.com /definition/quality_of_life, Oct., 2009 [Dec. 6, 2018].

[5] English Oxford Living Dictionaries. „Well-being“. Internet: https://en.oxforddictionaries.com/definition/well-being, Oct., 2009 [Dec. 6, 2018].

[6] Eurostat. „Quality of live“. Internet: https://ec.europa.eu/ eurostat/cache/infographs/qol/index_en.html, Oct. 25, 2018 [Nov. 28, 2018].

[7] P. Fobel and M. Fobelová. „Št́astie ako indikátor spoločenskej prosperity a udržatel'nosti života“. Proc. of the $X$ International Scientific Conference „Globalne konteksty poszanowania praw i wolności człowieka", 2017, pp. 72-77.

[8] S. Kesebir. „When economic growth doesn 't make countries happier". Internet: https://hbr.org/2016/04/wheneconomic-growth-doesnt-make-countries-happier, Oct. 10, 2016 [Dec. 6, 2018].

[9] A.C. Michalos. „Business Ethics and the quality of life“. Encyclopedia of Applied Ethics, $2^{\text {nd }}$ ed., vol. 4. R. Chadwick, Ed. Amsterdam: Elsevier Academic Press, 2012, p. 363. 
[10] Numbeo. "Cost of living“. Internet: https://www.numbeo.com/cost-of-living, [Nov. 28, 2018].

[11] Organisation for Economic Co-operation and Development (OECD). „Better Life Index“. Internet: http://www.oecdbetterlifeindex.org/\#/11111111111, [Aug. 16, 2018].

[12] J. Rifkin. Európsky sen. Ako Európska vízia budúcnosti politiky zatienila americký sen. Praha: Publishing ELK, 2005.

prof. PhDr. Daniela Fobelová, PhD.

Silesian University of Technology

Faculty of Organization and Management

ul. Roosevelta 26-28, 41-800 Zabrze, Poland

University of Matej Bel in Banská Bystrica

Department of Ethics and Applied Ethics

Tajovského 40, 97401 Banská Bystrica, Slovak Republic

e-mail: daniela.fobelova@umb.sk

\section{Mgr. Lukáš Moravec}

doc. PaedDr. Elena Bendíková, PhD.

University of Matej Bel in Banská Bystrica

Department of Ethics and Applied Ethics

Tajovského 40, 97401 Banská Bystrica, Slovak Republic

e-mail: lukas.moravec@umb.sk

elena.bendikova@umb.sk
[13] J.E. Stiglitz, A. Sen and J.P. Fitoussi. „Report by the Commission on the Measurement of Economic Performance and Social Progress". Internet: https://ec.europa.eu/eurostat/documents/118025/1181 23/Fitoussi+Commission+report, Jan. 5, 2009 [Jan. 4, 2018].

[14] World Health Organization (WHO). "Quality of life". Internet: http://www.who.int/healthinfo/survey/whoqolqualityoflife/en/, [Nov. 28, 2018]. 